УДК 346.3.347.191

DOI https://doi.org/10.32849/2663-5313/2019.11.14

\title{
Ліна Дорошенко,
}

канд. юрид. наук, дочент,

доцент кафедри иивільного права і процесу

Донеиького національного університету імені Василя Стуса

\section{КОРПОРАТИВНІ ДОГОВОРИ В НАЦІОНАЛЬНОМУ ПРАВІ ТА В ПРАВІ КРАЇН АНГЛО-АМЕРИКАНСЬКОЇ ПРАВОВОЇ СИСТЕМИ}

У статті проаналізовано теоретичні і практичні питання, що виникають у регулюванні корпоративного договору в Україні та в країнах англо-американської правової системи. Розглянуто тенезу законодавства країн загального права щодо укладення та дії корпоративного договору, а також становлення вітчизняного законодавства в иій сфері. У дослідженні міститься загальна характеристика змін акціонерного національного законодавства про договір між акціонерами товариства та положень нового інституту корпоративного договору в законодавстві, яке визначає правовий статус товариств з обмеженою та додатковою відповідальністю. Здійснено порівняльний аналіз предмета правового регулювання корпоративного договору в Україні та в англійському праві. Виокремлено групи умов договору, що становлять його предмет, проаналізовано критерії дійсності корпоративних договорів у країнах англо-американської правової системи. Розглянуто сутність порядків нормативного закріплення інституту корпоративного договору в законодавстві США, систематизовано підстави визнання судом недійсними корпоративних договорів у иій крайні. На підставі аналізу законодавства Великобританї̈ та США та практики його застосування визначаються основні закономірності розвитку доктринальних підходів до поняття, правової природи та засад визначення умов дійсності корпоративного договору; висвітлено кониептуальноправові підходи до формування положень щодо підстав недійсності таких договорів. Встановлено, що в законодавстві та юридичній літературі немає єдиного підходу щодо поняття, предмета корпоративного договору, його сторін, змісту, виконання, тому з метою розробки єдиного доктринального підходу, а також визначення шляхів удосконалення начіонального корпоративного законодавства в иій сфері проаналізовано позитивний досвід правової регламентації корпоративних договорів у країнах англо-американської правової системи щодо иих категорій. Стаття присвячена також дослідженню процесів гармонізаиї украйнського корпоративного законодавства $з$ корпоративним законодавством країн загального права в частині регламентаиії корпоративного договору, оціниі того, які норми права країн англо-американської правової системи у иій сфері були імплементовані у вітчизняне законодавство. Обгрунтовано пропозиціи щодо можливості впровадження окремих положень законодавства англо-американської правової системи в українське корпоративне законодавство.

Ключові слова: договір між акціонерами товариства, корпоративні права, управління корпоративними правами, господарські товариства.

Постановка проблеми. Світова поширеність корпоративних договорів зумовлена неможливістю врегулювання певних відносин між учасниками в установчих документах. I саме корпоративні договори в багатьох країнах є дієвим засобом захисту прав інвесторів і популярним механізмом, що дозволяє ефективно регулювати процес корпоративного управління в конкретному товаристві, передбачати шляхи розв'язання конфліктів між учасниками, встановлювати кворум, порядок голосування, які є відмінними від вимог, встановлених законом.
На відміну від нашої країни корпоративні договори за кордоном не тільки давно нормативно інституціоналізовані, але й активно застосовуються у бізнес-практиці. Так, корпоративне управління в 31 \% публічних компаній Бельгії було структуровано за допомогою корпоративних договорів, в Італії таких компаній - $23 \%$, у Франції - 18 \%, в Іспанії - $13 \%$, у Греції - $6 \%$, у Литві таких компаній $21 \%$, в Бразилії - 25 \%, у Великобританії - 5 \%, [1, с. 171]. Напрацьований досвід інших країн, які протягом тривалого часу успішно застосовують інститут корпора- 
тивного договору (а особливо це стосується країн англо-американської правової системи, звідки походить таке правове явище, як корпоративний договір), дає серйозне підгрунтя для України щодо врахування помилок та недоліків у їх застосуванні.

Ця законодавча новела стала одним із найбільш значущих нововведень у корпоративному законодавстві і знайшла своє відображення у Законі України «Про внесення змін до деяких законодавчих актів України щодо корпоративних договорів» [2], в якому було запроваджено та врегульовано новий договір, що отримав назву «договір між акціонерами товариствами» (відповідні зміни внесені в Закон України «Про акціонерні товариства» (ст. 261 Закону України «Про акціонерні товариства» [3])). Через короткий проміжок часу відбулося прийняття Закону України «Про товариства з обмеженою та додатковою відповідальністю» (далі - Закон про ТОВ та ТДВ) [4], яке стало еволюційним етапом реформування корпоративного законодавства. Положеннями ч. 1, 2 ст. 7 Закону України про ТОВ та ТДВ учасникам товариств 3 обмеженою та додатковою відповідальністю надається можливість для врегулювання відносин у сфері здійснення їніх повноважень за допомогою корпоративного договору, який визначається як договір, за яким учасники товариства зобовязуються реалізовувати свої права та повноваження певним чином або утримуватися від їх реалізації. У зв'язку з такою істотною зміною акціонерного законодавства в цьому напрямі, набранням чинності Законом про ТОВ та ТДВ та іншими численними спробами «апгрейдити» корпоративне законодавство в цілому та положення щодо договору між учасниками товариства зокрема, а також у зв'язку з наявністю усталеного законодавства та напрацьованої практики англо-американської правової системи, породженням якої і є корпоративний договір, доцільним видається здійснення порівняльно-правового дослідження питань регулювання корпоративного договору в Україні та країнах англо-американської правової системи.

Аналіз останніх досліджень і публікацій. Питанням поняття, правової природи, предмета, змісту договору, укладеного між учасниками товариства $з$ метою реалізації їхніх прав, приділили увагу ряд учених, таких як: В. К. Андрєєв, В. А. Бєлов, М. С. Варюшин, О. М. Вінник, Ю. М. Жорнокуй, В. А. Лаптєв, Д. В. Ломакін, В. Луць, К. О. Осипенко, I. В. Спасибо-Фатєєва, М. М. Сигидин та ін., але що стосується вітчизняних вчених, то наукові дослідження ними в цій сфері проводились до появи нового корпоративного законодавства і, відповідно, без можливості порівняти його позитивні і негативні аспекти 3 положеннями зарубіжного законодавства. Актуальною тему дослідження робить той факт, що таке явище, як «корпоративний договір», донедавна взагалі не мало напрацювань ні у вітчизняній правовій теорії, ні в українській юридичній практиці, а відповідні норми, які натепер встановлюють положення щодо корпоративного договору, запозичені із зарубіжної практики, зокрема 3 англійського загального права, що поширене в США, Великобританії, тому сьогодні $\epsilon$ нагальна потреба у перегляді їх розуміння та застосування.

Метою статті є комплексний науковий аналіз теоретичних і практичних питань, що виникають у разі застосування такого регулятора відносин, як корпоративний договір, задля визначення шляхів удосконалення українського законодавства з урахуванням досвіду правової регламентації корпоративних договорів у країнах англоамериканської правової системи.

Виклад основного матеріалу. Корпоративний договір як специфічний договірний механізм регулювання корпоративних відносин генетично пов'язаний з правом країн англо-американської правової системи. Якщо говорити про етимологію словосполучення «корпоративний договір», то його походженням треба завдячувати сім'ї загального права. У міжнародній практиці корпоративний договір відомий під назвою «shareholder agreements». Термін «share» перекладається одночасно як «частка, пай, акція». Поняття «shareholder» є родовим і означає власника частки в статутному капіталі (воно бере своє походження з англо-американської правової системи, в якій немає розмежування категорій осіб, як в українському праві, на акціонера, засновника/учасника ТОВ). Загалом словосполучення «shareholder agreement» правильно розуміти не як акціонерну угоду (як у буквальному перекладі), а як договір щодо корпоративних прав у всіх можливих видах господарських товариств.

На думку вчених, специфіка правового регулювання корпоративних договорів в англо-американському праві зумовлена сприйняттям договірної концепції юридичної особи [5, с. 22]. Перші згадки про один із видів корпоративних договорів трапляються в рішеннях англійських судів уже в 40-х рр. XIX століття. Слід зазначити, що в $1840-\mathrm{x}$ рр. термін «shareholders agreement» означав установчий договір акціонерного товариства, що визначав розмір статутного капіталу і порядок щорічного розподілення дивідендів. Нор- 
мативне закріплення в Limited Liability Act 1855 i Joint Stock Companies Act 1856 принципу обмеженої відповідальності учасників призвело до розмежування в англійській доктрині власне корпоративних відносин між акціонерною компанією та акціонерами, які регулюються установчими документами, і відносини акціонерів між собою, що перейшли до розряду зобов'язальних. Оскільки в останньому вищезазначеному нормативному акті установчі документи акціонерної компанії чітко розмежували як «Memorandum of association» (установчий договір), що укладається під час заснування, дійсність якого не залежала від зміни складу акціонерів, i «Articles of association» (статут), який затверджується акціонерами в тому разі, якщо вони виявили бажання змінити положення типового статуту, «shareholders agreement» втратив установчий характер і набув статус зобов'язальної угоди учасників компанії щодо здійснення належних їм корпоративних прав, про що свідчить і судова практика [6, с. 93].

В англійській практиці вже тоді траплялися угоди між акціонерами і самою компанією, згідно з положеннями яких визнавалося можливим укладення угоди між компанією та акціонером у частині встановлення, наприклад, договірного зобов'язання не ліквідувати компанію до виконання певних умов, а також мали місце договори, що містили зобов'язання голосувати по акціях у певний спосіб.

Як відзначається в зарубіжній літературі, в той період корпоративні договори не тільки компенсували акціонерам втрачені опції управління, властиві товариствам, але і дозволили зберегти організаційно-правову форму акціонерної компанії 3 обмеженою відповідальністю учасників [7, с. 745-746].

У США починаючи 3 1850-х $\mathrm{pp}$. з'являються перші згадки про корпоративні договори, до яких можна віднести «voting agreement», «pooling agreement» (угоди акціонерів про обмеження права розпорядження акціями), «shareholders agreement» (акціонерні угоди про порядок корпоративного управління) i «voting trust agreement» (угоди про заснування голосуючого трасту). Судова практика виходила 3 того, що, хоча і забороняється змінювати імперативні стандарти корпоративного управління, акціонери мають право укладати між собою договори 3 метою здійснення права голосу за належними їм акціями, наприклад, віддавати голоси за певних кандидатів у раду директорів або утворити «voting trust», керівники якого проголосують на загальних зборах за певних кандидатів. Схожа практика про- стежується у справі Faulds V. Yates, де суд визнав такою, що підлягає захисту, угоду мажоритарних акціонерів про визначення порядку голосування акціями з метою встановлення корпоративного контролю. Ситуація полягала в тому, що акції були придбані одночасно 3 приєднанням до акціонерної угоди, за якою голосування за придбаними сторонами акціями протягом пяти років здійснюється в рамках «єдиного блоку». Спільна позиція в рамках «єдиного блоку» вироблялася голосуванням учасників на попередніх зборах. Один з учасників, який був не згоден $з$ позицією «єдиного блоку», намагався проголосувати самостійно, але голова зборів акціонерів зарахував його голос до «єдиного блоку». Спроби учасника оскаржити результати голосування були нерезультативними, оскільки позиція суду полягала в тому, що рішення про голосування «єдиним блоком» $є$ легітимним і пов'язує сторони зобов'язанням, яке підлягає судовому захисту, тому суд дійшов висновку, що сторони уклали договір про передачу прав голосу за акціями, який не може бути визнаний недійсним [8].

Крім позитивної судової практики, у розвитку локального регулювання корпоративних відносин на початкових етапах мало місце i несприйняття судовою системою договірних конструкцій між акціонерами. Наприклад, були судові рішення, в яких суд дійшов висновку, що, дотримуючись принципів загального права, кожен акціонер має право здійснювати право голосу 3 акцій вільно від будь-яких зобов'язань за корпоративним договором. Останні визнавалися такими, що не підлягають судовому захисту на підставі того, що суперечать публічному порядку. Суди у своїх рішеннях дотримувалися принципу, що акціонер, голосуючи самостійно, переслідує інтереси компанії, а у разі укладання корпоративного договору, який обмежує здійснення на власний розсуд такої дії, можуть бути досягнуті цілі, що суперечать інтересам компанії.

На підставі аналізу судових справ можна систематизувати підстави визнання корпоративних договорів недійсними, які визначила судова система США, а саме, договір визнавався недійсним у разі:

1) якщо він зобов'язував акціонера голосувати певним чином або утримуватися від голосування через інститут трасту, оскільки правомочності голосувати по акціях не можна відокремити від права власності на останні, які не підлягають розщепленню як право власності, а також не можуть бути обмежені. Такі договори, згідно з позицією суду, суперечили вимогам публічного порядку; 
2) включення до змісту договору положень, які зобов'язують акціонера голосувати певним чином на загальних зборах акціонерів, оскільки подібним чином досягалися цілі конкретних акціонерів, але не компанії в цілому, що може суперечити публічним інтересам;

3) відсутності підстави укладення договору, тобто зустрічного задоволення;

4) загальним правилом виступала заборона на перетворення корпоративної організаційно-правової форми ведення бізнесу на форму товариства шляхом укладення угоди про голосування.

Питання дійсності корпоративних договорів були врегульовані тільки з прийняттям Model Business Corporation Act в 1950 р., положення якого містили норми, що регулюють, по-перше, голосування за дорученням, по-друге, порядок заснування голосуючих трастів [9]. Так, згідно з положеннями цього нормативного акта, будь-яке число акціонерів мало право укласти договір про заснування голосуючого трасту, передавши акції в управління трасту, але не більше ніж на десять років. Після цього договори акціонерів про голосування стали визнаватися дійсними.

Антагонізм принципу «неприпустимості підміни інтересів корпорації інтересами акціонерів» і практики укладення «shareholders' agreements» був знятий шляхом нормативного закріплення законодавством штатів закритої корпорації як організаційно-правової форми ведення бізнесу в 40-60-і рр. ХХ століття [10, с. 80]. У рішеннях судів тих років корпоративні договори, які змінювали порядок управління корпорацією, передбачений статутом, та заміщали інтереси корпорації інтересами її акціонерів у закритих корпораціях, визнавалися дійсними і такими, що підлягають захисту. Наприклад, такі корпоративні договори містили положення, згідно 3 якими акціонери зобов'язувалися голосувати за обрання один одного директорами компанії; в разі смерті одного з акціонерів дружина останнього мала право призначити директора на власний розсуд; у разі смерті одного 3 акціонерів дружині останнього повинен був виплачуватися з бюджету компанії щомісяця протягом п'яти років річний директорський оклад їі покійного чоловіка в подвійному розмірі.

Верховний суд одного зі штатів сформулював такі критерії дійсності подібних корпоративних договорів: 1) відсутність порушення публічних інтересів; 2) відсутність претензій з боку міноритарних акціонерів; 3) не заподіяння шкоди інтересам зовнішніх кредиторів; 4) дотримання імперативних норм чинного законодавства.
У законодавстві США склалося два порядки нормативного закріплення інституту корпоративних договорів. Суть першого порядку полягає в тому, що ряд штатів (Делавер, Гаваї, Огайо, Теннесі, Мічиган) імплементували правила Model Business Corporation Act тільки щодо договорів про заснування голосуючих трастів і акціонерних договорів щодо голосування. Другий підхід відображений у корпоративному законодавстві штатів Айдахо, Небраска, Міннесота, Юта, Вайомінг, згідно з яким корпоративний договір регулює також і положення щодо порядку корпоративного управління. Внаслідок такої законодавчої політики тема корпоративних договорів у юридичній науці і судовій практиці США перестала бути актуальною вже у другій половині XX століття. Сучасна судова практика не містить прецедентних положень. Крім того, корпоративні договори в публічних компаніях США, на відміну від приватних компаній, практично не застосовуються через те, що права міноритарних акціонерів захищені законодавством, що виключає необхідність вдаватися до таких договірних механізмів, як корпоративний договір.

У Великобританії питання визнання корпоративних договорів довгий час залишалися відкритими, про що свідчить суперечлива судова практика. Однак із прийняттям у 2006 р. оновленого закону про компанії корпоративний договір в закритих компаніях міг містити умови, відмінні від положень статуту, в тому числі передбачати застереження про перевагу договірних умов перед статутними [11, с. 126]. Такий корпоративний договір повинен бути укладений усіма акціонерами, а також депонований в реєструючому органі [12]. Згідно з п. 17 Закону про компанії установчі документи закритої компанії включають в себе статут, резолюції акціонерів та корпоративні договори.

В англійській юридичній літературі зазначається, що предмет регулювання корпоративного договору охоплює широке коло питань. Можна виокремити такі групи умов договору, що становлять його предмет: 1) питання, які належать до регламентації напрямів діяльності компанії; 2) розподіл вкладів засновників у статутний капітал; 3) визначення обсягу прав, які надаються 3 акцій, складу акціонерів компанії; 4) питання корпоративного управління компанією (зокрема, регламентація необхідної кількості голосів для прийняття того чи іншого питання; порядок розв'язання тупикових ситуацій); 5) фінансові питання - регламентація положень внутрішніх документів компанії стосовно виплати 
дивідендів, порядку підготовки бізнес-планів; 6) питання докапіталізації компанії (наприклад, умови додаткової емісії акцій) 7) питання надання звітності й іншої інформації акціонерам компанії; 8) порядок розбудови відносин із залежними підприємствами (дочірніми компаніями), відокремленими структурними підрозділами головною компанією; 9) питання передачі акцій компанії.

Перелік питань, які становлять предмет даного договору є відкритим і може охоплювати будь-які питання, які пов'язані з управлінням і діяльністю компанії. Виходячи 3 такого широкого кола питань, може скластися враження, що такий договір є додатком до статуту, що конкретизує його положення. Або, взагалі, його положення дублюють положення статуту. Але це не так, тому що корпоративний договір та статут компаній мають різні правові властивості в англійському праві. Договірні положення не мають за загальним правилом пріоритету над положеннями статуту компанії. У разі якщо корпоративний договір охоплює ті сфери регламентації, які регулюються статутом компанії, то такий договір (чи його окремі положення) не будуть мати юридичної сили, якщо тільки він не буде зареєстрований у Реєстраційній палаті компаній (Companies House). У такому випадку цей договір розглядається англійськими судами як невід'ємна частина установчих документів (статуту) компанії.

У вітчизняному законодавстві положеннями ст. 261 Закону України «Про акціонерні товариства», якою відповідний закон доповнено 23.03.2017 року, розкривається дефініція «договір між акціонерами товариства», під яким слід розуміти письмовий договір, предметом якого є реалізація акціонерами - власниками простих та привілейованих акцій - прав на акції та/або прав за акціями, передбачених законодавством, статутом та іншими внутрішніми документами товариства. Предметом договору між акціонерами не може бути зобов'язання сторони цього договору голосувати згідно з вказівками органів управління товариства, щодо акцій якого укладений цей договір, крім випадків, якщо стороною договору є особа, яка одночасно входить до складу органу управління такого товариства. М. М. Сигидин акцентує увагу на специфічності предмета такого договору - управління учасниками юридичної особи корпоративного типу належними їм корпоративними правами [13, с. 4].

Вищезазначеною нормою Закону України «Про акціонерні товариства» встановлюється перелік можливих положень такого договору між акціонерами, а саме:
- зобов'язання реалізувати у спосіб, передбачений таким договором, свої права та/або утримуватися від реалізації зазначених прав;

- можливість передбачення обов'язку сторін договору голосувати у спосіб, передбачений таким договором, на загальних зборах акціонерів;

- обов'язок погоджувати придбання або відчуження акцій за заздалегідь визначеною ціною та/або у разі настання визначених у договорі обставин, утримуватися від відчуження акцій до настання визначених у договорі обставин, вчиняти інші дії, пов'язані 3 управлінням товариством, його припиненням або виділенням з нього нового товариства;

- положення щодо того, що інформація про зміст договору між акціонерами не підлягає розкриттю та є конфіденційною;

- можливість передбачати способи забезпечення виконання зобов'язань, що випливають із такого договору, та заходи відповідальності за невиконання або неналежне виконання таких зобов'язань;

- договір між акціонерами може передбачати умови або порядок визначення умов, на яких акціонер - сторона договору - вправі або зобов'язаний придбати або продати акції товариства, та визначати випадки (які можуть залежати чи не залежати від дій сторін), коли таке право або обов'язок виникає.

\section{Висновки}

На підставі викладеного вище ми можемо зробити такі висновки, що мають враховуватися під час визначення основних напрямів розвитку української національної правової системи у сфері правової регламентації корпоративних договорів:

- з'ясовано, що поява корпоративних договорів у Великобританії і США в середині XIX ст. була викликана дефіцитом гнучких організаційно-правових форм ведення бізнесу і консервативністю судів загального права, які не визнавали акціонерних товариств. Стосовно сформованих сфер застосування можна узагальнити, що корпоративні договори в англо-американській правовій системі отримали розмежування, в тому числі нормативне, на договори про заснування голосуючого трасту ("voting trust agreements"), договори про голосування ("voting agreements"), договори про обмеження права розпорядження акціями ("pooling agreements"), характерні для публічних та приватних компаній, і договори про порядок корпоративного управління ("shareholders' agreements"), сфера використання яких локалізована лише в приватних 
компаніях. Сучасне англо-американське законодавство передбачає вищевикладену видову диференціацію регулювання корпоративних договорів. Поява корпоративного договору в українському законодавстві зумовлена недосконалістю вітчизняного корпоративного законодавства і сподіваннями, що він стане ефективним інструментом регулювання організаційно-господарських відносин всередині господарських товариств, що зумовлене його гнучким характером, оперативністю внесення змін, конфіденційнім характером, зрозумілістю для іноземних інвесторів;

- доведено, що межі предмета договору, що досліджується, істотно відрізняються в українському праві та праві країн англо-саксонської правової сім'ї. В останній концептуально межі предмета договору про здійснення прав акціонерів є надзвичайно широкими та охоплюють практично всі питання управління і діяльності компанією. Це зумовлено тим, що, якщо дотримано певних умов, зазначений договір може змінити навіть статут компанії. В українському законодавстві предметом корпоративного договору є регламентація порядку реалізації корпоративних прав учасників товариства. У національному праві договір між акціонерами товариства не може визначати структуру органів управління товариства і їхню компетенцію, тому предмет регулювання такого договору у вітчизняному законодавстві $€$ значно вужчим, ніж у країнах сім'ї загального права. Договір між акціонерами товариства в українському законодавстві не може самостійно породжувати нові корпоративні права чи обов'язки, які не надані або не покладені на учасника законом або статутом акціонерного товариства.

Таким чином, запровадження інституту корпоративного договору в Україні є логічним етапом розвитку вітчизняного корпоративного права за аналогією з розвитком законодавства країн 3 розвинутими ринковими відносинами, де такі договори грунтуються на загальних положеннях договірного права та давно стали поширеною та усталеною практикою.

\section{Список використаних джерел:}

1. Андреев В.К., Лаптев В.А. Корпоративное право современной России : монография. 2-е изд., перер. и доп. Москва: Проспект, 2017. 352 с.

2. Про внесення змін до деяких законодавчих актів України щодо корпоративних договорів : Закон України від 23 березня 2017 р. № 1984-VIII. Відомості Верховної Ради України. 2018. № 10. Ст. 52. (Із змінами).

3. Про акціонерні товариства : Закон України від 17 вересня 2008 р. № 514-VI. Відомості Верховної Ради України. 2008. №o 50-51. Ст. 384. (Із змінами).

4. Про товариства 3 обмеженою та додатковою відповідальністю : Закон України від 06 лютого 2018 р. № 2275-VIII. Відомості Верховної Ради України. 2018. № 13. Ст. 69. (Із змінами).

5. Ломакин Д.В. Договоры об осуществлении прав участников хозяйственных обществ как новелла корпоративного законодательства. Вестник ВАС РФ. 2009. № 8. С. 6-26.

6. Корпоративное право: актуальные проблемы / Д.В. Ломакин, Ф.А. Афаунова, О.И. Гентовт, К.О. Осипенко и др.; под общ. ред. Д.В. Ломакина. Москва: Инфотропик Медиа, 2015. 256 с

7. Sealy L, Worthington S. Cases and Materials in Company Law. Oxford University Press, 2007. P. 745-746.

8. Puddephatt v. Leith [1916] 1 Ch 200. Справочно-поисковая система «Westlaw database». URL: https://uk.practicallaw.thomsonreuters.com/ D-016-7158?transitionType $=$ Default\&contextData =\%28sc.Default\%29 (дата звернення: 06.09.2019).

9. The Model Business Corporation Act and Corporate Governance: An Enabling Statute Moves Toward Normative Standards. URL: https://scholarship.law.duke.edu/cgi/viewcontent. cgi? article $=1607 \&$ context $=l c p \quad$ (дата 06.09.2019)

10. Сыродоева О.Н. Акционерное право США и России (сравнительный анализ). Москва: Издательство Спарк, 1996. 112 c.

11. Полковников Г.В. Английское право о компаниях: закон и практика : учебное пособие. Москва: Изд-во «НИМП», 1999. 240 с.

12. Закон о компаниях 2006. Уставы Blackstone по корпоративному праву 2010-2011. 14-е издание под редакцией Дерека френча. Издательство Оксфордского Университета, 2011. С. 289.

13. Сигидин М.М. Корпоративний договір : автореф. дис. ... канд. юрид. наук: 12.00 .03 ІваноФранківськ, 2016. 20 с.

Theoretical and practical questions which arise up at the regulation of corporate agreement in Ukraine and in the countries of the English-American legal system were analysed in the article. Genesis of legislation of countries of common law in relation to the process on making and action of corporate agreement, and the enhance of state legislation were considered in this field. The study contains a general description of changes in joint stock national legislation on the agreement between shareholders of companies and the provisions of the new institute of corporate agreement in the legislation, which determines the legal status of limited liability companies and companies with additional liability. The comparative analysis of the article of the legal regulation of corporate agreement is carried out in Ukraine and in the English law, the groups of conditions of the agreement relating its object were identified, the criteria of reality of corporate agreements in the 
countries of the English-American legal system were analysed. Essence of the procedure of the normative fixing of the institute of corporate agreement were considered in the legislation of the USA, the grounds for the court's invalidation of corporate agreement in this country were systematized. On the basis of the analysis of the legislation of the UK and the USA and the practice of its application, the basic regularities of the development of doctrinal approaches to the concept, legal nature and bases of determining the terms of validity of the corporate agreement have been derermined; conceptual and legal approaches to the formation of provisions on the grounds of invalidity of such agreements were outlined. It was found that there is not the unique approach in legislation and legal literature considering the concept, subject of corporate agreement, its sides, maintenance and implementation, consequently, with the purpose of development of the unique doctrine approach, and also determination of ways of improvement of national corporate legislation in this field have been analysed positive experience of legal regulation of corporate agreements in the countries of the English-American legal system in relation to these categories. The article is also devoted to the study of the harmonization processes of the Ukrainian corporate law with the corporate law of the countries of common law regarding the regulation of the corporate agreement, the assessment of norms of law of the countries of Anglo-American legal system in this field that have been implemented in the domestic legislation. The suggestions on the possibility of implementing certain provisions of the law of the Anglo-American legal system into the Ukrainian corporate law were justified.

Key words: agreement between shareholders by societies, corporate rights, corporate rights management, economic societies. 